Зона В. Мркаљ

mrkalj@ikomline.net

(Филолошки факултет - Српска књижевност, Београд)

\title{
ПОЈАМ КОРЕЛАЦИЈЕ У МЕТОДИЦИ НАСТАВЕ
}

\section{САЖЕТАК}

Појам „корелација” у наставној терминологији има неколико значења. Поред уобичајеног схватања, корелација се успоставља и између оријентационих циљева наставе и стратегија учења. Овај појам, шире гледано, везује се и за објашњење појма „методика“. Појам корелације тумачи се у склопу повезивања садржаја подобласти једног предмета, а затим као међупредметни и међуобласни однос. У овом раду пратиће се успостављање корелација са предметом српски језик и књижевност који се, као доминантан, проучава и у основној и у средњој школи.

КЉУЧНЕ РЕЧИ: корелација, методика, настава, учење, наставни циљеви и задаци, српски језик, књижевност. 
ојам „корелација” у наставној терминологији има неколико значења. Најшире и најопштије значење корелације односи се на узајамност, повезаност или зависност, односно чињеницу да су две ствари или варијабиле тако повезане да је промена у једној праћена одговарајућим или паралелним појавама у другој.

Поред уобичајеног схватања корелације (међусобно повезивање и однос садржаја предмета који се изучавају у школи, именовано као „хоризонтално” и „вертикално“), ваља нагласити да се корелација успоставља и између оријентационих циљева наставе и стратегије учења. ${ }^{1)}$ Приликом међупредметног повезивања, под учењем се не сматра само усвајање знања. Уче се и методе и стратегије усвајања знања (како потражити и пронаћи информацију, организовати одговор, планирати, обликовати, визуелизовати одговоре различитог типа, препознати, разумети, применити и вредновати знање).

На тај начин, успостављање корелација тиче се димензија знања, то јест, главних типова и подтипова знања:

Чињенично знање: основни елементи које ученици треба да знају да би били упознати са одговарајућом научном дисциплином и да би могли да решавају проблеме у одређеној области (терминологија; специфични детаљи и елементи);

Концептуално знање: повезаност основних елемената појединих предметности са ширим структурама које омогућавају заједничко функционисање (класификација и категорије; принципи и генерализације; теорије, модели и структуре);

Процедурално знање: подстиче како нешто чинити - уз истраживање, позивање на задате критеријуме, коришћење вештина, техника и метода (специфичне

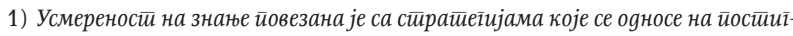
нуће. Међуйим, усмереносй на самойоиврђивање веома је слабо йовезана са

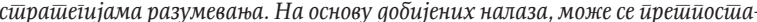

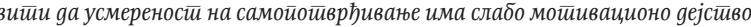

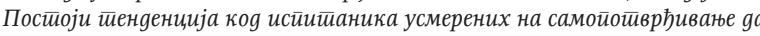

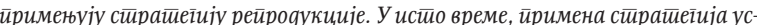
мерених на йосиииінуће значајно је йовезана са усмереношћу на знане и са

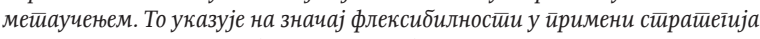
у склаяу са заяаиима који се йостиављају у настиави. Друіа исираживања о gноса између оријеншиаи, ија на ииљеве и стиратиетије учења указују gа корелаиије између ових варијабли варирају у о оносу на узрасти, на основу иеїа

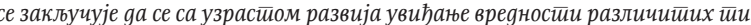

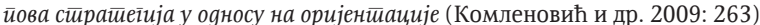

вештине и алгоритми; специфичне технике и методе; критеријуми за одабир одговарајућих поступака);

Метакогнитивно знање: уопштено знање о когнитивним процесима, као и свесност и разумевање властитих когнитивних процеса (стратешко знање; знање о когнитивним задацима, укључујући и одговарајуће контекстуално и кондиционално знање; самоспознаја).

Међупредметним саодносом, целовитим увидом у материју која се проучава, упоређивањем садржаја и указивањем на сличности и разлике унутар одређених наставних подручја, знање се усваја квалитетно и дугорочно.

Појам корелације, шире гледано, непосредно се може везати и за објашњење појма „методика“. Методика је истовремено и примењена (прагматичка) и теоријска научна дисциплина, која наставницима пружа одговарајућа знања, а уз њих и потребна умења. У њој се здружују начело сазнања и позитивна наставна искуства, те тако она остаје доследна неопходности сталног „јединства теорије и праксе“. У односу на посебне наставне предмете, развија се као специјална и професионално усмерена научна дисциплина. Најбитнија подручја методике су:

- циљеви и задаци наставе (образовни, васпитни и функционални) и начини њиховог остваривања;

- планирање и организовање наставног рада: наставни програми, годишњи и оперативни планови рада; структуре наставних часова, индивидуални и групни рад;

- корелација наставних подручја (у оквиру подобласти једног предмета и са другим наставним предметима);

- припремање наставника и ученика за успешан рад: истраживачки и домаћи задаци; припреме за обраду наставних јединица и извођење проблемске и стваралачке наставе уз мотивисање ученика;

- проучавање и примена наставне методологије: логичких, стручних и комуникационих метода; инвентивна примена наставних принципа и начела опште условности; 
- проналажење и стварање погодних наставних облика, поступака и методичких поставки и њихово примењивање у пракси;

- коришћење уџбеника, стручне литературе и наставних средстава.

Циљеви „методике” у целини су срачунати на богаћење и унапређивање наставне праксе, усмерени на постизање што бољих образовних и васпитних резултата.

Задаци које методика остварује у општем настојању да обогати и унапреди наставну праксу су следећи:

- проучава и истражује разне видове поступања у настави, проверава их, процењује и усавршава, те тако прибавља, образлаже и сугерише наставној пракси функционалне поступке и ваљане начине рада;

- усавршава наставнике и оспособљљава наставнички подмладак за успешно извођење наставе на свим подручјима наставног предмета;

- доприноси усавршавању наставних програма, уџбеника, стручне литературе и наставних средстава.

Саоднос одговарајућих методичких поступака и радњи, адекватан избор наставних метода, одабир „носећих" интеграционих чинилаца интерпретације књижевноуметничког текста, воде до квалитетних тумачења књижевних дела у настави, на одређеном нивоу обраде (интерпретација, приказ, осврт).

За интерпретацију књижевноуметничког текста најзначајнија је такозвана функиионална корелаиија. ${ }^{2)}$

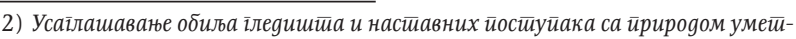

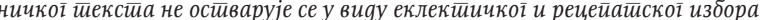

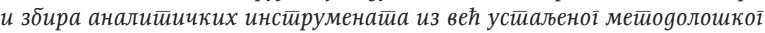

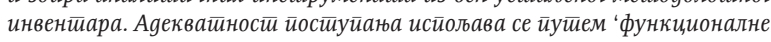
корелаиије' значајних іллеgишйа и уілова йосмайрања, који се не расийају у сиоредним ирравиима, већ се усмеравају на битине чињениие и воgеће вредносии уметиниикоі текстиа... Неке савременије книневнонауине

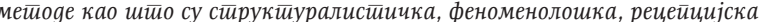
и семиотиска йовесне су за универзалније ироучавање књижевне уметинос-

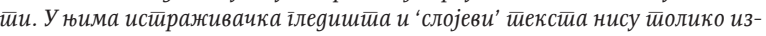

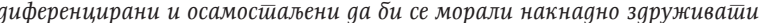
и синхронизоватии. Све ове метиоgе, наравно у својој неформализованој иримени и са већим сииеиеном корелаиије (као gа су сииворене да йомажу јеgна gруїој), омог̄ућавају слобоянији тиок истираживачке йажне и сазнајних асоцијаиија. Тиме се обезбеђује истовремени увия у више естешичиких иинилаи, који зајеgнички и истолобно, а никако сваки за себе и у искинутиој иостиавии, йобуђују уметиничке доживљаје. Књижевно gело се

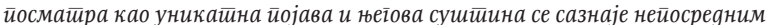

Како се корелација дефинише као међусобни однос, узајамна зависност, повезаност у хармоничну целину и сл. може се закључити да је најважнија особина корелативности - структуралност. Структура се препознаје као унутрашње начело које гради неки облик. Она представља невидљиву материју која својим смислом држи на окупу целину, то јест склоп неке појаве. Тиме се осећај појединца (читаоца) за јединство целовите форме проширује. Јединствено се не доживљава само књижевноуметничко дело, већ се оно спознаје као целина у пропорционалном односу с другим „делима” које читалац има у свести, сазнању и искуству. На тај начин се гради индивидуална перцептивна композиција која почива на хармонији универзалног: у том „сагласју” сваки део, сегмент, елемент нечега стоји у односу према неком другом, једнако значајном елементу. Овим

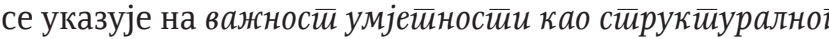
објеgињења свих сйознаја љуясккоі gуха йосииављених у о оносе свакоі йојеgиноі језика йојеgине умјейносиии, у сврху йроницаюа универзалноі реgа Прироgе и о оражавањ а йої реgа у човјеку (Huzjak 2005: 42).

Из корелације и пропорције (размере односа) проистичу саоднос и аналогија. Овај низ се често користи спонтано и у свакодневној комуникацији. Успостављање поредбеног склопа пре свега представља креативни, а не произвољни чин. Тако се у настави српског језика и књижевности приступа „компаративном проучавању” књижевноуметничких дела и одабраних текстова секундарне литературе (избор из критика, књижевне историје и теорије, речника, енциклопедија, информативних и научнопопуларних чланака итд.).

Улога корелација у настави може бити различита. Понекад се оне укључују у овај процес ради „мотивисања" ученика да прошире гледишта на књижевноуметнички текст који се интерпретира. У одређеним случајевима везују се за методичку радњу „локализо-

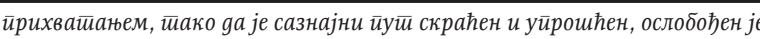

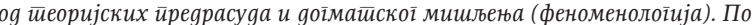
себно се уважавају функиионални ояноси, укуйни и иојединачни, између gелова (знакова и исказа) у уметиничком оріанизму (стирукичурализам)

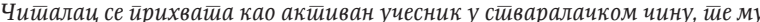
се и йосебно йризнаје све оно шйо је сам разложно сииворио и 'унео' у свей

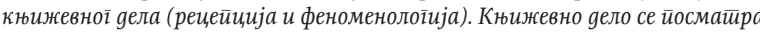

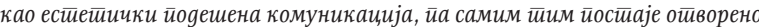
йрема иитиаоиу (Николић 1999: 195-197). 
вање" (нпр. у одређени историјски контекст), а њихов основни задатак је да омогуће остваривање „функционалних (практичних) циљева наставе" и да утичу на проширивање специфичних ученичких знања о наставној јединици која се проучава, као и општих знања. Тиме се омогућује широко постављање могућих наставних проблема и њихово решавање уз заузимање различитих тачака гледишта као полазишта у разматрању истог или сродног садржаја. Промишљене корелације (и унутар једног предмета и међупредметне) доприносе остваривању „принципа рационализације“, као и „принципа очигледности“, при чему се, у склопу обавештајних метода, посебно активира „метода показивања“.

Корелације се, да би се остварило усвајање и повезивање знања ученика и остварио саоднос тих знања у једну заједничку целину, морају предвидети месечним планом и програмом. Важно је знати проценити који је садржај најбоље обрађивати у међупредметном повезивању. Оваква процена захтева тимски рад и континуирану сарадњу свих чланова стручних већа у школи.

Дубљи смисао корелација назире се у повезаности образовно-васпитног процеса у хармоничну целину.

Успостављање корелација у настави врши се и ради остваривања „Циљева и задатака програма образовања“. 3) Многи наведени циљеви и задаци захтевају нужно повезивање наставних и ваннаставних садржаја, као и стварање узајамних односа међу школским предметима. Низ у том смислу најзначајнијих циљева и задатака, преузет је из уводника актуелних наставних програма за старије разреде основне школе:

- развијање свести о државној и националној припадности, неговање српске традиције и културе, као и традиције и културе националних мањина;

- развијање свести о значају заштите и очувања природе и животне средине;

- усвајање, разумевање и развој основних социјалних и моралних вредности демократски уређеног, хуманог и толерантног друштва;

3) Видети: Правилник о наставном програму за шести разред основног образовања и васпитања (2008). Службени йласник РС - Просвейни ілласник бр. 5/2008. Правилник о наставном програму за осми разред основног образовања и васпитања (2010). Службени ілласник РС - Просвейни іла сник бр. 2 /2010.
- развијање код деце и ученика радозналости и отворености за културе традиционалних цркава и верских заједница, као и етничке и верске толеранције, јачање поверења међу децом и ученицима и спречавање понашања која нарушавају остваривање права на различитост;

- поштовање права деце, људских и грађанских права и основних слобода и развијање способности за живот у демократски уређеном друштву;

- стицање знања о језику, књижевности и медијима релевантним за будуће образовање и професионални развој;

- оспособљавање ученика да користе стандардни матерњи језик, ефикасно комуницирају у усменом и писаном облику у различите сврхе;

- оспособљавање ученика да комуницирају у усменом и писаном облику на теме из свакодневног живота на страном језику;

- разумевање повезаности различитих научних дисциплина;

- разумевање и сналажење у садашњости и повезаности друштвених појава и процеса у простору и времену (Србија, Европа, свет);

- разумевање појава, процеса и односа у природи на основу знања физичких, хемијских и биолошких закона, модела и теорија;

- правилно формирање математичких појмова и стицање основних математичких знања и вештина;

- стицање способности за уочавање, формулисање, анализирање и решавање проблема;

- овладавање информационо-комуникационим технологијама;

- развијање вештина и техника уметничког изражавања;

- познавање вредности сопственог културног наслеђа и повезаности са другим културама и традицијама;

- развијање одговорног односа према сопственом здрављу и здрављу других.

Повезивање (интеграција) наставних садржаја у целину ученицима омогућује целовито уочавање појава, стицање и саображавање знања, уочавање важности стечених знања у свакодневном животу.

Корелација се као појам често појављује као један од захтева школског надзора, који је потребно испуни- 
ти приликом припремања за реализацију наставне јединице и у самом њеном спровођењу. ${ }^{4)}$ Реч корелација често је присутна у упутствима о методичкој реализацији наставног часа, а њено право значење махом остаје нејасно и неодређено. Овај тип корелације односи се на могућност функционалног повезивања наставних садржаја различитих предмета који се у настави проучавају. Када је реч о српском језику и књижевности, уобичајене су корелације са историјом, музичком и ликовном уметношћу, грађанским васпитањем, позориштем и филмом, понекад с географијом, филозофијом, психологијом, социологијом, веронауком, а ређе с математиком, биологијом, архитектуром. У уџбеницима она се формално појављују приликом увођења илустрација уз књижевноуметнички текст (српски језик - ликовна уметност), или описом доживљаја неке музичке композиције (српски језик - музичка култура), као и у радној апаратури.

Предмет српски језик и у основној и у средњој школи пружа многе могућности за успостављање различитих корелација:

- садржаја у оквиру самог предмета (успостављање веза међу подобластима предмета: Језик, Кюи-

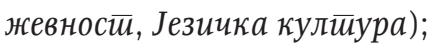

- садржаја у оквиру једног разреда, са различитим предметима (међупредметна хоризонтална корелација);

- садржаја истог и других предмета који су савладани у претходним разредима или ће тек бити укључени у наставно разматрање (међупредметна вертикална корелација);

- садржаја у вези са стицањем знања ширих од оних који су прописани школским програмима (међуобласна корелација, интердисциплинарност у настави).

4) Вреднује се у којој мери наставници подстичу ученике на корелације ради успешније примене знања:

- наставник препоручује ученицима да користе додатне изворе информација (часописе, стручне књиге, интернет...);

- подстиче ученике да при учењу новог садржаја користе знања и вештине стечене у другим областима;

- подстиче ученике да примене научено у свакодневном животу;

- заједно са ученицима прави програме за поједине ваннаставне активности, на основу ученичког интересовања;

- упознаје ученике са могућностима и начином коришћења школске опреме, интернета и литературе кроз ваннаставне и ваншколске активности (Правилник 2007)
Осми разред основне школе нарочито је погодан за часове систематизације градива који се могу комплексно организовати, уз увођење паралела са наученим градивом из других предмета, што доприноси стицању и развијању опште културе ученика. У том смислу могу се сугерисати следеће теме, значајне за остваривање оваквих повезивања:

- средњовековна уметност код Срба (12. и 13. век): архитектура (Студеница, Жича), фреско-сликарство (Милешева, Сопоћани), књижевност (Мирослављево јеванђеље, житија светитеља); српскословенски језик;

- српска уметност 1300-1371: архитектура (Грачаница), скулптура (Дечани), фреско-сликарство (Старо Нагоричано, Дечани). Иконе и минијатуре. Народна епска поезија;

- српска уметност 1371-1459: архитектура (Раваница), рељефна декорација и полихромија у обради фасаде (Каленић), фреско-сликарство (Манасија). Српски манастири у књижевности;

- опште одлике барока код Срба: архитектура (манастири Фрушке горе). Улога наставника књижевности у припремању радног материјала за ђачке екскурзије;

- настанак модерне српске државе. Први српски устанак (Карађорђе Петровић). Народне епске песме новијих времена. Слика српских кнезова у Мемоарима Проте Матеје Ненадовића;

- Други српски устанак и стицање аутономије (Милош Обреновић). Однос Милоша Обреновића и Вука Стефановића Караџића (Миодраг Поповић, Вук Сшефановић Караиић);

- стварање државе у Црној Гори (цетињска митрополија, Петар I, Петар II Петровић Његош, књаз Данило и књаз Никола). О Његошу као јунаку дела Писма из Ийалије Љубомира Ненадовића. Историјска основа Горскої вијени, П. Петровића Његоша;

- ослободилачки ратови 1876-1878. године и стицање независности Србије. Одабрана поезија Ђуре Јакшића. Романтизам у српској уметности;

- академски реализам у српској уметности (сликари Ђорђе Крстић, Паја Јовановић и Урош Предић; 
вајар Петар Убавкић. Приповедна проза српских реалиста;

- Србија од 1878. до 1903. године (проглашење краљевине, Милан и Александар Обреновић, политички живот и модернизација Србије). Сатирични и хумористички књижевноуметнички текстови;

- Србија у балканским ратовима и у Првом светском рату. Одабране песме Милутина Бојића и Владислава Петковића Диса;

- стварање заједничке државе Срба, Хрвата и Словенаца и њено постојање до 1941. године (политички, економски и културни живот, Александар и Павле Карађорђевић). Преглед значајних аутора и литерарних остварења хрватске и словеначке књижевности;

- Југославија у Другом светском рату. Стваралаштво Бранка Ћопића, Добрице Ћосића и других значајних писаца;

- Југославија после Другог светског рата (политички, економски и културни живот до распада СФРЈ 1991. године). Значајни писци и дела из тог периода;

- модерна и савремена уметност - правци и представници (Надежда Петровић, Петар Коњовић, Милена Павловић Барили, Мића Поповић, Марко Челебоновић, Петар Лубарда, Влада Величковић, Љуба Поповић, Оља Ивањицки...);

- допринос националне културе светској баштини (књижевност, музика, ликовна и примењена уметност, драмска и филмска уметност, телевизијско стваралаштво...);

- велика имена српске културе и науке која истовремено припадају и светској култури (Иво Андрић, Милош Црњански, Никола Тесла, Михаило Пупин, Милутин Миланковић, Данило Киш...);

- основне природно-географске одлике Србије (рељеф, клима, хидрографија, биљни и животињски свет). Национални паркови и заштита животне средине. Научнопопуларни и информативни текстови (читање, разумевање, издвајање битних информација; издвајање кључних речи; стварање сажетка...);
- становништво Србије (број, густина насељености, природни прираштај, миграције, структура - национална, језичка, верска, полна, радна, старосна). Раслојавање језика. Сеобе под Арсенијем Чарнојевићем (Сеобе I, Милош Црњански);

- опште привредно-географске карактеристике Србије (географске основе развоја пољопривреде, извори енергије и рудно богатство, индустријске гране и центри, саобраћај и важније саобраћајнице, туристички ресурси и туристички центри. Читање текстова нелинеарног типа;

- уметничке, народне и староградске песме за певање, на текстове народне и ауторске књижевности; однос мелодије и стиха; слушање вокалноинструменталне музике (опера Кошйана, Петар Коњовић, Шесйа и Јеgанаести а руковет, Стеван Мокрањац, опера Косово, Д. Јенко, Бияо - комад са певањем, Д. Јенко); композиције за певање и слушање: Боже иравgе, национална химна; Химна свейом Сави; Тамо далеко; Креће се лађа франиускка; Марш на Дрину...5)

Значајне корелације међу предметима српски језик и књижевност, музичка уметност и ликовна уметност остварене су у многим средњошколским читанкама. У уџбенику Кюижевносй са основама умейностии, намењеном војним гимназијама (Радовановић, Игњатовић и др. 1974) овакво повезивање нарочито је долазило до изражаја приликом обраде стилских праваца, то јест епоха романтизма и реализма. У оквиру романтизма, уз проучавање дела Гетеа, Бајрона, Пушкина, Игоа, Караџића, Његоша, Змаја, Костића, указивано је на музичко стваралаштво Шуберта, Шумана, Шопена, Берлиоза, Сметане, Лисинског, Чајковског, Станковића, Мокрањца и на ликовно стваралаштво Жерика, Делакроа, Гоје, Караса, Радоњића, Јакшића. Књижевност Балзака, Тургењева, Глишића, Толстоја, Лазаревића, Сремца, Домановића, Матавуља повезивана је са музичким делима Мусоргског, Бородина, Корсакова и

5) Значајан корак у сложеном остваривању односа међу садржајима важним за ученике и развијање њихове опште културе, разумевање традиционалних вредности и успостављање многих васпитних циљева наставе начињен је у Посебном йроїраму срйскої језика за уиенике у gијасйори (Посебан програм, 2006) 
Бизеа и илустрацијама Курбеа, Рјепина, Крстића, Буковца, Јовановића, приликом проучавања реализма.

Примере добрих и оригиналних корелација прона-

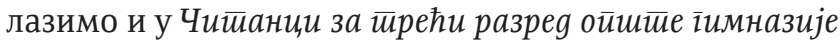
(Павловић, Јелушић 2008). Увид у одређене књижевноисторијске периоде обогаћен је паралелама из области науке, технологије, политике, историје, музичке и ликовне уметности, архитектуре, психологије, историје позоришта и филма. Следи пример повезивања наставних садржаја књижевности и филозофије дат у поменутом уџбенику.

У историји филозофије, још од античких времена, као централно питање појављује се интересовање о схватањима и виђењима живота, његовог устројства, односно начина на који постојање и свијет функционишу. Упореди два доминантна гледишта која су се издвајала у филозофији и често била предмет занимљивих и плодних разговора, расправа и подстицаја за промишљено сучељавање гледишта.

Panta rei-Cве тече

Ово је схватање према коме се цјелокупно устројство свијета доживљава као опште променљиво, покретно, подложно непрестаном кретању, преобликовању и непоновљивости.

Eternal Return - Вјечно враћање истог

Живот се окончава чином смрти; свако животно дешавање, као и сваки садржај живота, враћа се на исти начин и у истим временским периодима, без завршетка, непрестано.

Књижевно дјело такође је ризница бројних филозофских схватања живота која се у свијетлу дјела најчешће репрезентују у слоју идеја и универзалних значења. У мислима, гледиштима и ставовима писаца често се потврђују или оповргавају постојећи филозофски системи, а неријетко се и конституишу нека нова гледишта на живот и његов смисао.

Бескрајан, йлави круі̄. Уњему, звезgа.

...Tу је у њих улазила несвесна фрилозофија касабе: gа је

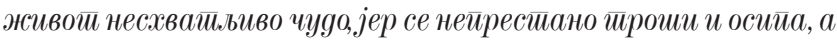
ийак йраје и сииоји чврсиоо..

Препознај из којих романа потичу слиједећи искази. Пореди их и тумачи у контексту представљених филозофских идеја. Установи које филозофске концепције живота у њима препознајеш. На који начин ти доживљаваш постојање? У којим животним садржајима препознајеш древну Хераклитову мисао о променљивости свега? А које животне околности ти потврђују да су животни садржаји вјечито враћање истог?

У актуелним читанкама за осми разред, различитих издавача, извршене су бројне и разноврсне коре- лације. У радној апаратури, уз књижевноуметничке текстове, наговештено је која се књижевна дела могу компаративно проучавати. Наглашена је улога организовања посета знаменитим задужбинама и музејима (Музеј Вука и Доситеја, Муселимов конак, Музеј Првог српског устанка у Ваљеву, задужбине Вука Караџића, Доситеја Обрадовића, Иве Андрића, Милоша Црњанског, Десанке Максимовић, Вукова кућа у Тршићу, Бранковина, Музеј Николе Тесле, Народна библиотека Србије, Универзитетска библиотека и др. У нове уџбенике се уводе и типови нелинеарних текстова чије разумевање је предвићено Сйанgарguма за крај обавезнот образовања ${ }^{6}$ (нпр. мапа са топонимима у вези са именом светог Саве; класификационе таблице; „путевима” Доситеја Обрадовића или Вука Караџића; хронолошки попис значајних људи и догађаја у одређеном историјском периоду и сл.). Многи аутори анегдотски су сагледани помоћу одабраних примера из секундарне литературе. Истакнути су значајни српски манастири (Милешева, Студеница, Сопоћани, Грачаница, Хиландар) и успостављене су континуиране везе између историјских, географских и књижевноуметничких садржаја. Дат је избор значења појединог биља из српских народних веровања о биљкама. Указано је на лепоту народне ношње српског народа (Увела ружа, Борисав Станковић). Уз књижевноуметниче текстове укључене су и врхунске илустрације дела најпознатијих домаћих и страних сликара.

У нове читанке уводе се и „кратки подсетници” о почетку историје филмске уметности, као и сегменти о историји позоришта. Ученици се позивају да слушају значајна дела класичне (озбиљне) музике док се припремају за самостално литерарно стваралаштво.

У актуелној Читани, за 8. разреg основне школе (Бајић, Мркаљ 2010), у оквиру првог тематског блока Гуслар, наведен је одломак из Политикиног Забавника (Умесйо рама за слику) који у настави може послужити за успостављање бројних међуобласних корелација (највише са историјом и различитим уметностима)

6) Видети: Предлог образовних стандарда за крај обавезног образовања (2010). Београд: Министарство просвете. (www.mp.gov.rs). Програм за самостално полагање завршног испита у вези са Образовним стандардима за крај обавезног образовања (2010). Београд: Завод за вредновање квалитета образовања и васпитања. (www.ceo.gov.rs). 
приликом обраде народне епске песме Почей $а к ~ \delta y-$ не йройив gахија, одломка из Мемоара Проте Матеје Ненадовића и других значајних књижевноуметничких текстова, тематски везаних за период од 1804. до 1813. године. Ученици се подстичу да овај одломак прочитају и додатно истраже садржаје који су побудили њихову посебну пажњу.

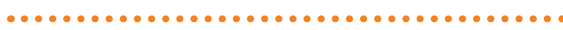

Пошто пажљиво прочиташ понуђени текст из Политикиног Забавника, издвој догађаје који су ти се учинили најважнијим за светску историју. Образложи која од поменутих дешавања сматраш посебно значајним и занимљивим.

Наведене податке можеш проверити увидом у историјску грађу (уџбенике историје, одговарајуће енциклопедије, историје уметности и друге изворе о овом периоду). Тако ћеш употпунити хронолошку слику времена, људи и догађаја. •.......................

Значајни историјски догађаји, овековечени делима врхунских сликара, „описани” су и ликовно, уношењем илустрација у читанке. Илустрације складно прате одломке из књижевноуметничких текстова и доприносе стварању потпунијег доживљаја уметничког дела, инспирисаног значајним историјским тренутком. Та-

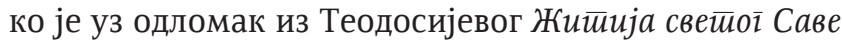
постављен инсерт са слике Стевана Алексића Сūaљи-

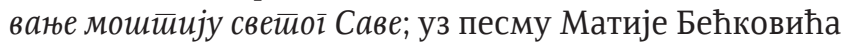
Прича о свейом Сави дат је лик светог Саве са фреске из манастира Милешева; одломак из Сеоба Милоша Црњанског прати илустрација дела Паје Јовановића Сеоба Срба; уз песму Ђуре Јакшића Ойацбина стоји илустративни прилог Девојка у илавом итд.

Смисао корелирања градива у основној школи добија своје пуно значење приликом планирања школских екскурзија. Стручна већа предлажу одредишта која ће се приликом реализовања екскурзија упознати и стварају програме екскурзија. Након усклађивања предлога школе и одабраног извођача екскурзије следи припремање материјала за ученике који ће, поред дружења на заједничком путовању, имати прилике и да се информишу о значајним дестинацијама које ће посетити и тако стекну здружена, слојевита и трајна знања.

Како смо управо сада пред реформом програма за средње школе и гимназије, могло би се размислити о неопходном повезивању градива различитих предмета и о делимичном укључивању корелативних садржаја као обавезних у програм српског језика и књижевности. Овим би се потцртала важност предмета Срйски језик u књижевности и ученицима би се омогућило да стекну увид у контекст (друштвени, историјски, стилски, психолошки), продубе своја већ стечена знања и тако их утврде, повежу и прошире, размишљајући о садржајима школских предмета креативно, гледано кроз специфичне призме сваког учесника у настави.

\section{Л И Т Е Р А Т У Р А}

- Бајић, Љ.; Мркаљ, 3. (2010). Читианка за 8. разреg основне школе. Београд: Завод за уџбенике и наставна средства.

- Закон о основама система образовања и васпитања (2006). Службени іласник РС бр. 6/2006.

- Комленовић, Ђ., Душица М. и др. (2009). Квалишеей и ефикасносии насйаве. Београд: Институт за педагошка истраживања - Педагошка теорија и пракса. Књ. 26.

- Николић, М. (1999). Мейоgика настиаве срйской језика и књижевности. Београд: Завод за уџбенике и наставна средства.

- Павловић, М.; Божена J. (2008). Чийанка за иирећи разреg

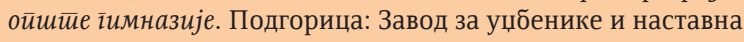
средства.

- Посебан иройрам основної образовања и васииитиаюа у иносиирансииву (2006). Београд: Завод за унапређивање образовања и васпитања.

- Правилник о наставном програму за шести разред основног образовања и васпитања (2008). Службени іласник PC Просвеиини иласник бр. 5/2008.

- Правилник о наставном програму за осми разред основног образовања и васпитања (2010). Службени ілласник PC Просвеиини іласник бр. 2 /2010.

- Правилник о стручно-педагошком надзору (2007). Службени іласник РС - Просветини ілласник бр. 19/2007.

- Преgлої образовних сйанgарgа за крај обавезної образовања (2010). Београд: Министарство просвете. (www.mp.gov.rs).

- Проїрам за самосйално йолаїање завриної исӣийа у вези са Образовним сйанgарgима за крај обавезноі образовања (2010). Београд: Завод за вредновање квалитета образовања и васпитања. (www.ceo.gov.rs).

- Радовановић, С., Игњатовић, М. и др. (1974). Кюижевносй са основама уметиностии. Књига II. Београд: Војноиздавачки завод.

- Huzjak, M. (2001). Korelacija u nastavi: strukturalni prijevod. Metodika. 2/3 Vol. 2. 
Zona V. Mrkalj

\title{
THE CONCEPT OF CORRELATION
}

\section{IN THE METHODOLOGY OF TEACHING}

\begin{abstract}
Summary
The concept of correlation in teaching terminology has several meanings. In addition to the usual understanding of the correlation (interconnection and relationship between the content of subjects taught in school, designated as horizontal and vertical), the correlation is established between the objectives of teaching and learning strategies. This term, more broadly, is related to the explanation of methodology. The concept of correlation is interpreted in the linking of content sub-areas of an subject, and then as the inter-relationship between subjects. This paper will follow the establishment of relationships with the subject Serbian language and literature which is, as a dominant, studied both in primary and secondary schools.
\end{abstract}

Key words: correlation, methodics, teaching, learning, teaching objectives and tasks, the Serbian language, literature. 